\title{
ПРОФЕССИОНАЛЬНОЕ ОБУЧЕНИЕ
}

УДК 378.2

\section{МОДЕЛЬ ПОДГОТОВКИ ВНУТРИФИРМЕННЫХ ПРЕПОДАВАТЕЛЕЙ ПРОИЗВОДСТВЕННОГО ПРЕДПРИЯТИЯ}

\author{
А.Г. Колзина ${ }^{1}$, Р.Н. Зарипов ${ }^{2}$ \\ ${ }^{1}$ АОУ ДПО УР «Институт развития образования», Ижевск \\ ${ }^{2}$ ФГБОУ ВО «Казанский национальный исследовательский \\ технологический университет», Казань
}

DOI: $10.26456 /$ vtpsyped/2020.2.167

Внешнее обучение сотрудников предприятия не всегда учитывает специфику конкретного производства, поэтому более целесообразной представляется подготовка внутрифирменных преподавателей из числа авторитетных специалистов, способных передать собственный профессиональный опыт и полученные знания. Авторы статьи описывают модель подготовки внутрифирменных преподавателей. Достоинством модели является то, что она учитывает индивидуальные особенности преподавателя и образовательные запросы предприятия, ориентирующегося на федеральную и региональную политику повышения эффективности и внедрение бережливого производства.

Ключевые слова: внутрифирменное обучение, внутрифирменные преподаватели, преподавательские компетенции, педагогическая система, андрагогика.

Выполнение задач современного производства требует своевременной подготовки (переподготовки) и повышения квалификации рабочих, специалистов, служащих и руководителей предприятия. К учебному процессу могут привлекаться как сторонние преподаватели учебных заведений и организаций, так и внутрифирменные преподаватели.

В настоящее время используется несколько форм реализации задач обучения персонала, предусматривающих направление на внешнее обучение; взаимодействие с образовательными организациями, погружение внешних преподавателей, тренеров, консультантов в тематику предприятия; создание внутрикорпоративной системы знаний; участие внутрифирменных преподавателей; деятельность инновационных корпоративных университетов (научноисследовательских институтов, исследовательских подразделений), ориентированных на поиск рационального решения крупных проблем предприятия, направлений совершенствования производства и менеджмента, постановку инновационных задач и развитие эффективных процессов, в рамках которых происходит объединение обучающих функций и функций научного и консультационного

$$
\text { - } 167 \text { - }
$$


характера [5]; реализацию кластер-интегрированной системы «образование - наука - производство» и привлечение субъектов к разработке инновационных проектов, способствующих объединению интеллектуальных ресурсов в перспективные наукоемкие области хозяйственной деятельности [5, с. 115].

Однако, по оценкам специалистов, внешнее обучение сотрудников предприятия, в том числе с использованием различных тренингов и семинаров, не всегда учитывает специфику конкретного производства. Более целесообразной представляется подготовка внутренних преподавателей-наставников, которых компании готовят из числа своих сотрудников, обучающих впоследствии весь остальной персонал. В этом случае в качестве преподавателей выбираются авторитетные специалисты, пользующиеся уважением своих коллег, способные передавать собственный профессиональный опыт и полученные знания.

Исследователи отмечают, что внутрифирменное обучение должно быть направлено как на текущие процессы, так и на опережающее развитие производства. Текущие процессы требуют непрерывного пополнения актуальных профессиональных знаний, понимания применяемой технологии производства продуктов и услуг. Это относится и к новичкам, которые учатся, получая новые знания, и к опытным, давно работающим сотрудникам, которые часто перестают задумываться над выполнением типовых действий, выполняя работу менее качественно, чем новички. Базовые знания могут изучаться на местах, а наиболее сложные и ответственные вопросы - на занятиях с преподавателем. Что касается опережающего внутрифирменного обучения, то оно должно способствовать «генерации новых идей для производства, применению современных образцов техники, разработке и внедрению новых технологий, а также позволять обеспечить предприятие высококвалифицированными работниками. Обновление технико-технологической базы производства, сотрудничество с зарубежными партнерами, выход России из экономического кризиса это всё напрямую связано с опережающим внутрифирменным обучением персонала» [8, с. 3].

Корпоративные ценности и стратегические цели, традиции, лучший опыт предприятия и инновации может собрать, переработать и транслировать исключительно прогрессивная, мотивированная и подготовленная группа сотрудников - внутрифирменных преподавателей.

Предлагаемая нами модель подготовки внутрифирменных преподавателей, разработанная на основе анализа научнопедагогической литературы, включает четыре блока: организационноцелевой, проектировочный, технологический и диагностический.

Организационно-целевой блок отражает цель, задачи, теоретикометодологическую базу подготовки внутрифирменных преподавателей, 
а также принципы и подходы к её организации.

Исходя из анализа теоретических положений современной дидактики, педагогической квалиметрии, нормативно-правовых документов сферы профессионального обучения и дополнительного профессионального образования определены общедидактические и специфические принципы подготовки внутрифирменных преподавателей. Группа общедидактических принципов определяет обоснованность всех действий по организации процесса подготовки и включает: принцип научности, ориентирующий на усвоение конкретных знаний, связанных с данным производством, через обобщенные теоретические знания, «наукоемкость деятельности в сфере производства порождает, как следствие, наукоемкость всех процедур обучения» [2]; принщии системности, требующий установления структурно-функциональных связей между разнородными элементами профессионально-ориентированных знаний; принции сознательности $u$ самостоятельности, состоящий в формировании субъектной позиции внутрифирменного преподавателя за счет развития его способности к рефлексии, осознания личностно-значимых мотивов учебной деятельности и удовлетворения потребности в самообразовании.

Вторую группу образуют специфические принципы: опережающей профессиональной подготовки, предполагающей включение в процесс обучения внутрифирменных преподавателей элементов поиска, исследования, проектирования, развития и обеспечение не только его своевременной адаптации к существующим условиям профессиональной деятельности, но и готовность к будущему заказу предприятия, выполнение которого может потребовать изменений в организации труда; индивидуализации, отражающей необходимость построения образовательной деятельности на основе индивидуальных особенностей обучающихся, создания оптимальных условий для реализации их потенциальных возможностей на занятиях и во внеаудиторной деятельности; оптилальности, требующей рациональности в организации всех элементов процесса подготовки внутрифирменных преподавателей, достижения максимально возможных результатов при минимально необходимых затратах времени и усилий; самоорганизации, направленной на помощь обучающимся в освоении навыков рационального учения, самостоятельного поиска информации и ее использования в профессионально-педагогической деятельности; интерактивности, обеспечивающей взаимодействие всех участников педагогического процесса, приобретение и обмен знаниями между обучающимися и преподавателями, совместный анализ профессиональных задач и разработку рекомендаций под руководством преподавателя.

На наш взгляд, реализовать рассмотренные принципы возможно при использовании комплекса дополняющих друг друга подходов: системного, деятельностного, компетентностного, личностно- 
ориентированного, акмеологического и квалиметрического.

C позиций системного подхода процесс подготовки внутрифирменных преподавателей можно рассматривать как гибкую систему, учитывающую специфику конкретного промышленного предприятия в совокупности всех его внешних и внутренних профессиональных связей.

Деятельностный подход (П.Я. Гальперин, А.Н. Леонтьев, С.Л. Рубинштейн, Н.Ф. Талызина и др.) направлен на подготовку преподавателей, способных не только передавать опыт своей профессиональной деятельности, но и обладающих компетенциями собственного профессионально-педагогического развития и решения организационно-методических задач внутрифирменного обучения.

Компетентностный подход моделирует ожидаемый результат подготовки внутрифирменных преподавателей в виде сформированной профессионально-педагогической компетенции, ориентированной на задачи обучения и повышения квалификации работников предприятия.

Личностно-ориентированный подход (Э.Ф. Зеер, В.В. Сериков, И.С. Якиманская и др.) предполагает создание условий для раскрытия и последующего целенаправленного развития личностных черт обучающихся.

Важнейшими требованиями к педагогу являются способность к постоянному профессиональному саморазвитию и самосовершенствованию, что актуализирует использование в процессе подготовки внутрифирменных преподавателей акмеологического подхода. По словам Б.Г. Ананьева, «общее и специальное образование для взрослых выполняет не только культурную и техническую функцию, но и помогает высокой жизнеспособности и жизнестойкости человека. Развитие интеллекта и личности, способность к обучению и постоянному самообразованию взрослого человека - огромная сила, противостоящая инволюционным процессам» [5, с. 25].

Квалиметрический подход, предусматривающий использование метода групповых экспертных оценок [9], ориентирован на выявление структуры и содержания профессионально-педагогической компетенции внутрифирменных преподавателей, а также уровней их готовности к обучающей деятельности.

Выявленная нами структура профессионально-педагогической компетенции представлена в проектировочном блоке модели. Она включает следующие функциональные компоненты, конкретизирующие компетентностно-ориентированные цели подготовки внутрифирменных преподавателей: гностический, характеризующий степень владения предметными и психолого-педагогическими знаниями, стремление к приобретению новых знаний и исследованию образовательных ситуаций, а также способность к самопознанию (собственной личности и деятельности); проектировочный, подразумевающий выполнение совместных действий для решения задач обучения и профессиональной 
деятельности (в т. ч. стратегических и приоритетных задач предприятия); конструктивный, направленный на конструирование преподавателем собственной деятельности и повышение активности учащихся при достижении ближних целей обучения (цели урока, цикла занятий); коммуникативный, устанавливающий профессионально-личностное взаимодействие преподавателя, обучающихся, руководителей с целью достижения дидактических (воспитательных и образовательных) целей и целей предприятия; организационный, предусматривающий наличие у педагога способности к организации собственной деятельности и управлению активностью обучающихся; оценочныц̆, связанный с умением использовать методики и инструментарий оценки качества подготовки обучающихся, а также со сформированностью навыков самооценки; прогностический, характеризующий способность внутрифирменного преподавателя к прогнозированию возможного влияния на качество профессиональной деятельности результатов текущей образовательной деятельности обучающегося.

К основаниям проектирования процесса подготовки внутрифирменных преподавателей следует отнести: заказ предприятия, определяемый федеральной и региональной политикой повышения эффективности и внедрением бережливого производства, цели которого: безопасность, качество, производительность, экономия, культура (постоянные улучшения и ориентация на клиента); индивидуальные особенности преподавателя, характеризующие его возраст, опыт, образование, профессию, должность, психологические особенности; образовательные запросы обучающихся, выявленные с учетом описания содержательных элементов педагогических систем Н.В. Кузьминой, охватывающих результат (цель), содержание образования (учебную информацию), средства её передачи (средства педагогической коммуникации), обучающегося и преподавателя [4; 7, с. 11-13].

Педагогический проект образовательных технологий, по нашему мнению, включает в себя: представление планируемых результатов в виде диагностично поставленных целей, определение и структурирование содержания образования, основанного на прогностической модели специалиста, выбор технологий обучения, соответствующих целям каждого этапа образовательного процесса, системное использование индивидуальных видов учебной деятельности и систему мониторинга [2, с. 15].

Например, заявка от заказчика (обучающегося, его руководителя) должна включать ожидаемый результат обучения (конкретные знания, умения, опыт, компетенции,) или измеримые показатели производительности (результативности), в частности эффективность продвижения по целевым и ценностным показателям предприятия: безопасность, качество, производительность, экономия, культура (см. выше). Под «обучающиимися» следует понимать группу смешанного состава, в которую могут входить: 
a) обучающиеся разного опыта и подготовки для организации практикоориентированного взаимообучения, так как длительный профессиональный (либо управленческий) опыт может обогатить обучение практическим значением преподаваемого материала; б) специалисты разных уровней; в) представители смежных подразделений, «поставщиков» и «потребителей» процесса (по принципу корпоративности). Такой смешанный состав способствует сплочению коллектива и формированию полезных деловых/профессиональных связей.

Необходимо предусматривать и использование достоверной и доступной информации, включающей в т. ч. корпоративную базу знаний. В качестве средств передачи информации следует использовать всё многообразие существующих информационно-коммуникативных технологий, доступные материально-технические возможности, рабочую среду.

Проектирование процесса подготовки внутрифирменного преподавателя требует учета следующей его специфики: кратковременность u интенсивность, которые обусловлены необходимостью подготовки грамотного внутрифирменного преподавателя в сжатые сроки с акцентом на профессиональном (управленческом) содержании; необходимость выполнения заказа предприятия в строго установленные сроки при минимальных затратах, соблюдении всех правил безопасности и лояльности квалифицированного персонала, что обеспечит предприятию готовность выдержать любой экономический кризис; различие возрастных, психологических особенностей обучающихся, уровня их теоретической и профессиональной подготовки, учет которых позволяет индивидуализировать процесс подготовки внутрифирменных преподавателей за счет выявления их потребностей, мотивов и профессиональных проблем, обеспечения условий для самореализации и самоуправления во всех сферах жизни, включая учебную [6].

Технологический блок модели представлен содержанием подготовки внутрифирменных преподавателей промышленного предприятия и ее организационно-методическим сопровождением.

Представленные в модели этапы процесса подготовки внутрифирменных преподавателей соответствуют теории обучения взрослых Д. Колба (Experiental Learning Model) [10, 11]. Согласно этой теории, существуют 4 способа обучения: опыт, рефлексия, концептуализация, экспериментирование. Взрослые обучаются одним или несколькими из этих способов одновременно. Причём считается, что, не пройдя все эти способы, невозможно развить требуемые компетенции.

Использование данных способов предусмотрено в базовой части подготовки (авторский курс) внутрифирменных преподавателей, направленной на развитие функциональных компонентов их профессионально-педагогической компетенции. В рамках базовой части осуществляются: 1) развитие коммуникативных умений через обмен опытом и его обсуждение; 2) развитие оценочных, прогностических 
умений через рефлексию опыта и установление обратной связи с обучающимися (позитивной, корректирующей и развивающей), а также размышление, прогнозирование и выстраивание гипотез; 3) развитие гностических, конструктивньхх умений через концептуализацию, изучение, обобщение, схематизацию, презентацию признанных теорий и правил, а также конструирование занятий с опорой на опыт и гипотетические рассуждения группы; 4) развитие проектировочных, организащионных умений через проектную деятельность, экспериментирование, приобретение опыта и закрепление умений в практической деятельности.

Применение данных способов в обучающей деятельности требуют от преподавателя определённых умений и навыков. Учитывая, что обучающая деятельность не является основной для внутрифирменного преподавателя, следует предусматривать в процессе его подготовки некоторые компенсирующие воздействия, восполняющие недостающие умения. Индивидуализировать этот процесс возможно в рамках индивидуальных образовательныхх траекторий и при наличии соответствующего им организачионно-методического сопровождения.

В нашем случае установлены 4 индивидуальные траектории: трудовая, коммуникативная, учебная, игровая. Их характеристика дана в табл. 1.

Диагностический блок характеризует систему оценивания и планируемый результат подготовки внутрифирменных преподавателей. Система оценивания включает критерии, шкалу, методику и средства оценивания, которые позволяют получить количественную оценку уровня готовности преподавателей к обучающей деятельности. В нашем случае установлены три уровня готовности: базовый, технологический и экспертный. Их характеристика дана в табл. 2.

Преподаватель с базовым уровнем готовности имеет общее представление о педагогической деятельности. Технологический уровень характеризует преподавателя, который способен использовать в процессе обучения современные педагогические технологии. Преподаватель с экспертным уровнем готовности может научить преподавать.

В качестве планируемого результата выступает переход внутрифирменных преподавателей на более высокий уровень готовности к организации процесса обучения на промышленном предприятии. Готовность в данном случае понимается как сформировавшееся в процессе целенаправленной подготовки целостное структурное образование личности, ядро которого составляют коммуникативные, конструктивные, гностические, проектировочные, организационные, оценочные и прогностические компоненты.

Обобщая вышеизложенное, можно сделать вывод, что рассмотренная модель подготовки внутрифирменных преподавателей направлена на достижение системного результата. С одной стороны, это подготовка компетентных внутрифирменных преподавателей, а с другой повышение квалификации работников промышленных предприятий. 
Вестник ТвГУ. Серия "Педагогика и психология". 2020. № 2(51)

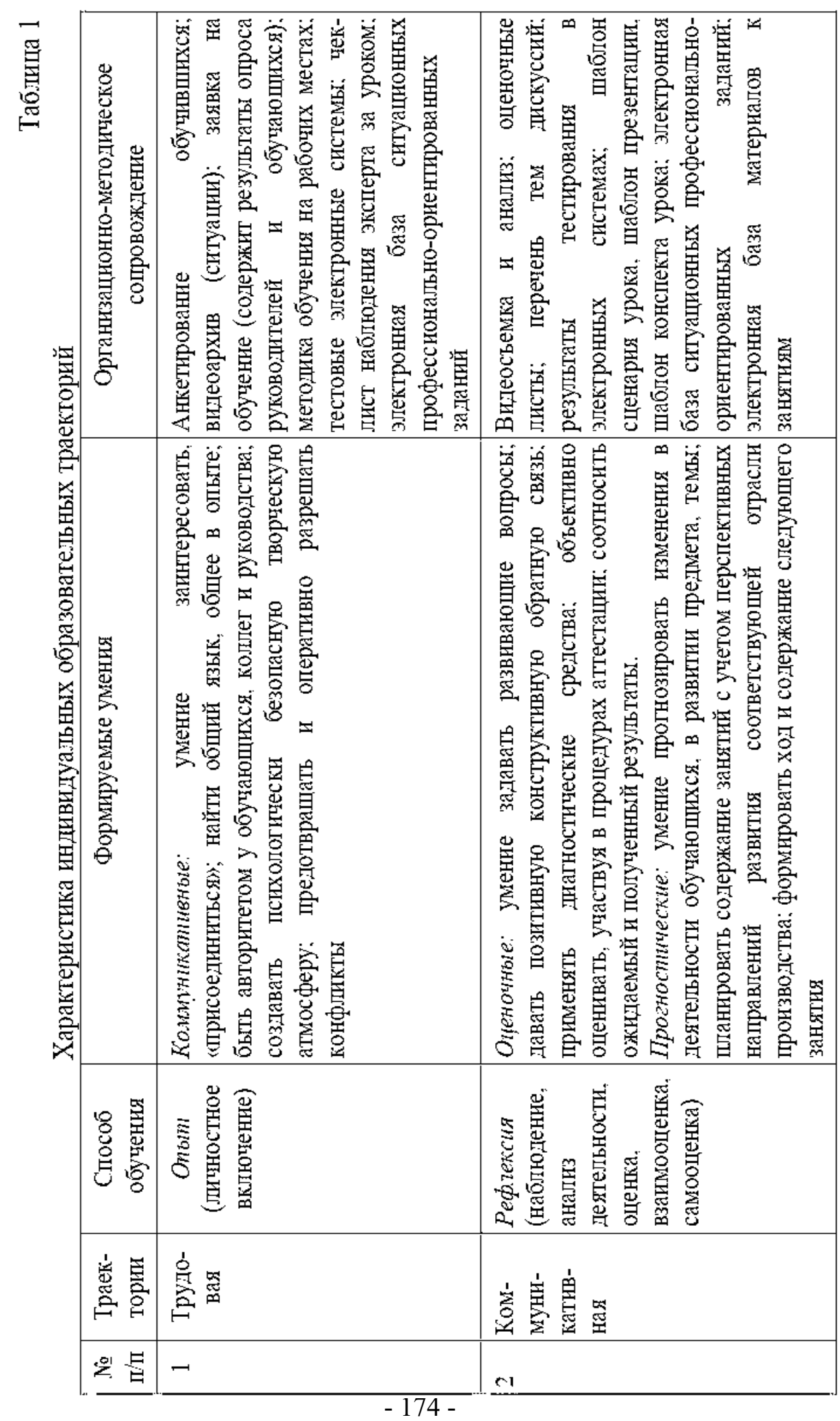


Вестник ТвГУ. Серия "Педагогика и психология". 2020. № 2(51)

\begin{tabular}{|c|c|c|}
\hline 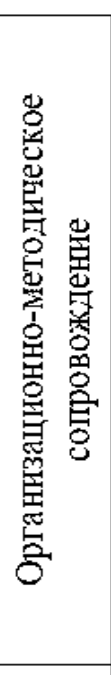 & 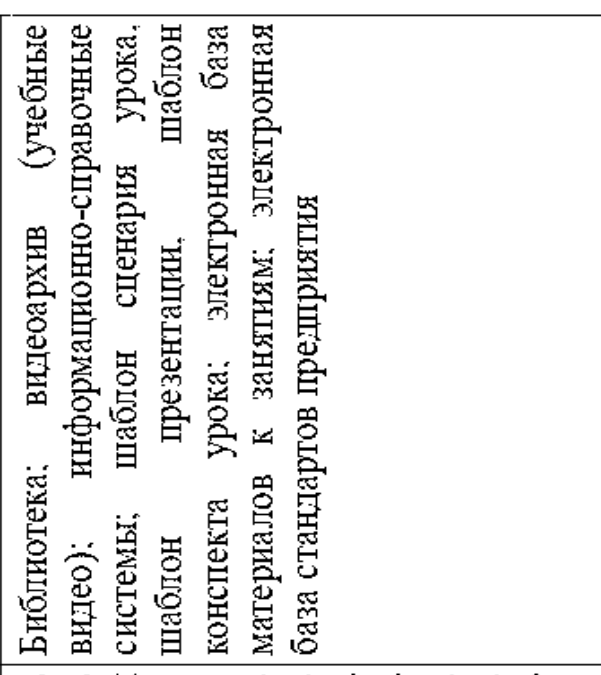 & 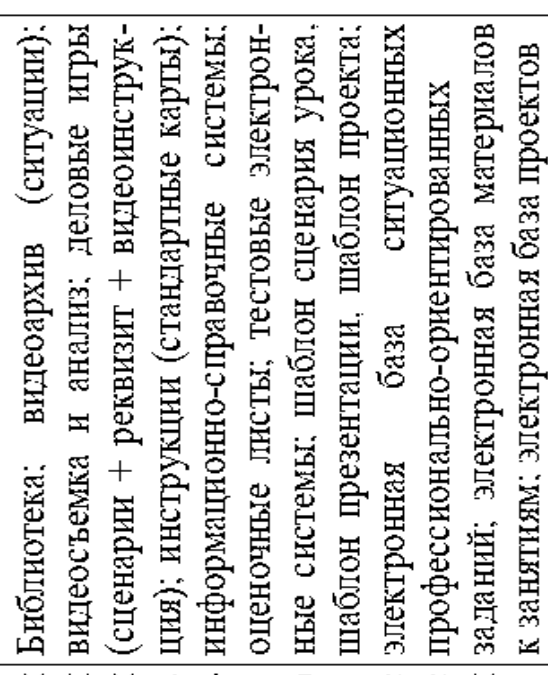 \\
\hline 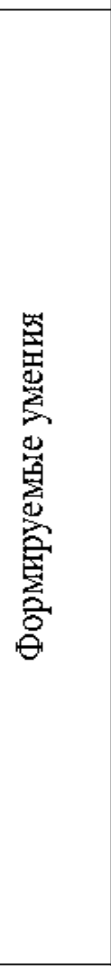 & 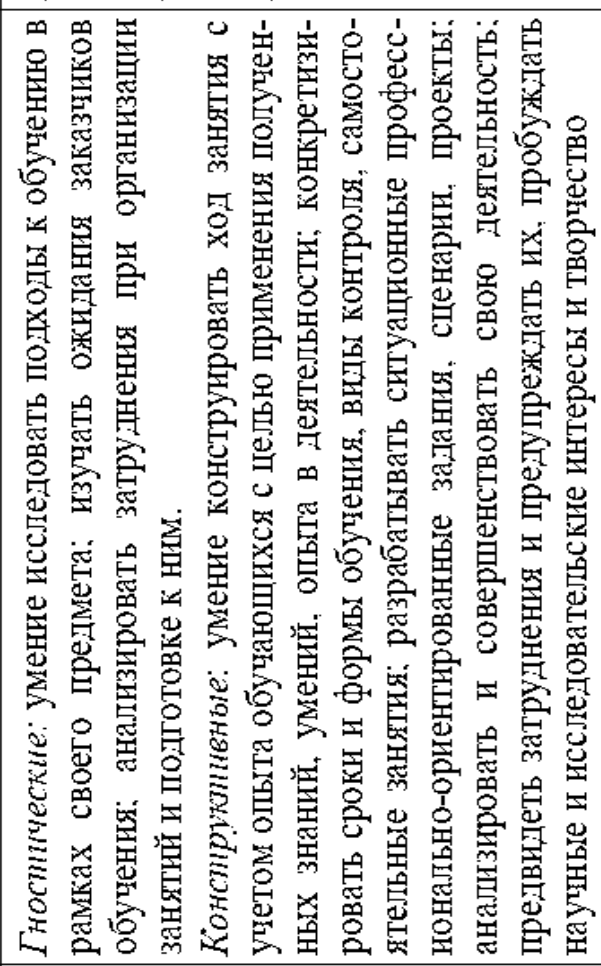 & 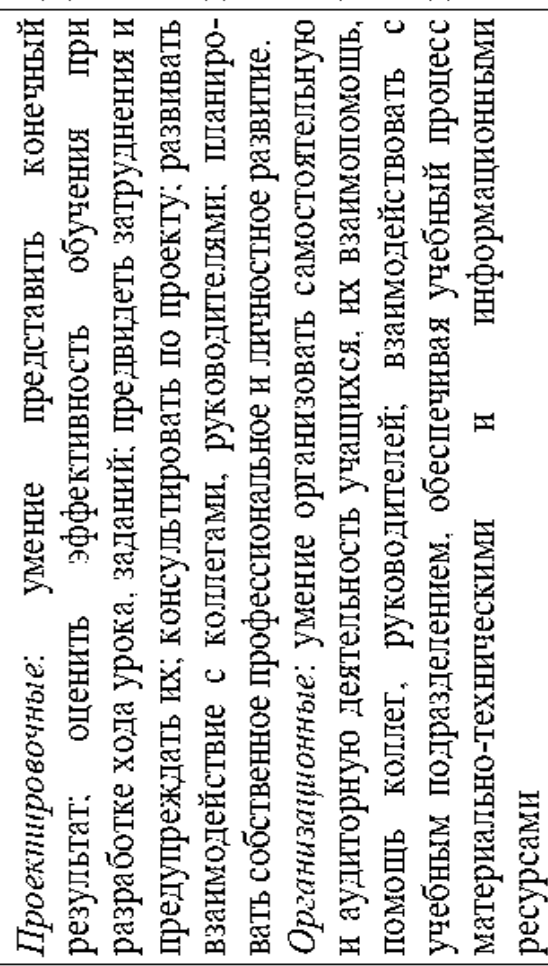 \\
\hline 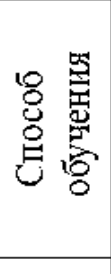 & 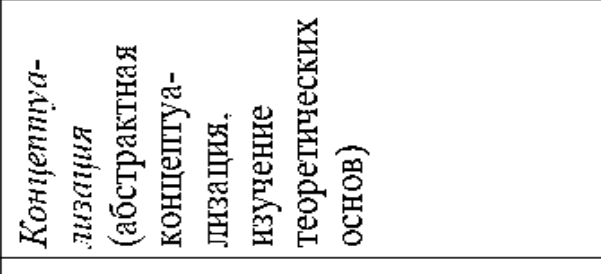 & 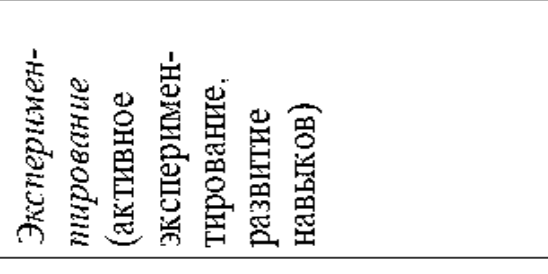 \\
\hline 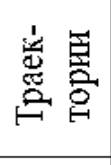 & & $\begin{array}{l}\text { 昡 } \\
\text { 总 } \\
\text { 㤐 }\end{array}$ \\
\hline 况昌 & $\mathrm{m}$ & \\
\hline
\end{tabular}

- 175 - 
Таблица 2

Характеристика уровней готовности внутрифирменных преподавателей

\begin{tabular}{|c|c|c|c|}
\hline \multirow{2}{*}{$\begin{array}{c}\text { Критерии оценивания уровня } \\
\text { готовности }\end{array}$} & \multicolumn{3}{|c|}{ Уровни готовности } \\
\hline & Базовый & $\begin{array}{l}\text { Техноло- } \\
\text { гический }\end{array}$ & Экспертный \\
\hline $\begin{array}{l}\text { Компоненты: } \\
\text { тивный, коммуника- } \\
\text { гностический, понтруктивный, } \\
\text { вочный, ороектиро- } \\
\text { оценочный, прогностический }\end{array}$ & $\begin{array}{c}1-3 \\
\text { компонента }\end{array}$ & $\begin{array}{c}4-5 \\
\text { компоненто } \\
\text { в }\end{array}$ & 6-7 компонентов \\
\hline Вид выбранной траектории & Трудовая & $\begin{array}{c}\text { Трудовая } \\
\text { Коммуни- } \\
\text { кативная } \\
\text { Учебная }\end{array}$ & $\begin{array}{c}\text { Трудовая } \\
\text { Коммуни- } \\
\text { кативная } \\
\text { Учебная } \\
\text { Игровая }\end{array}$ \\
\hline $\begin{array}{l}\text { Экспертная оценка препода- } \\
\text { вания по содержательным } \\
\text { элементам педагогических } \\
\text { систем (наблюдателями и } \\
\text { обучающимися) [3, с. 92-95] }\end{array}$ & Ниже $70 \%$ & $\begin{array}{c}\text { От } 71 \text { до } 95 \\
\%\end{array}$ & От 96 до $100 \%$ \\
\hline $\begin{array}{l}\text { Использование материалов } \\
\text { организационно- } \\
\text { методического сопровождения } \\
\text { внутрифирменных } \\
\text { преподавателей }\end{array}$ & $\begin{array}{c}\text { Не } \\
\text { использует }\end{array}$ & Использует & $\begin{array}{c}\text { Самостоятельно } \\
\text { разрабатывает } \\
\text { материалы к } \\
\text { занятию, } \\
\text { участвует в } \\
\text { организационно- } \\
\text { методическом } \\
\text { сопровождении } \\
\text { темы }\end{array}$ \\
\hline $\begin{array}{l}\text { Направленность на задачи } \\
\text { предприятия: безопасность, } \\
\text { качество, производительность, } \\
\text { экономия, культура (постоян- } \\
\text { ные улучшения и ориентация } \\
\text { на клиента) [1, с. 8-9] }\end{array}$ & 1-2 задачи & 3-4 задачи & 5 задач \\
\hline
\end{tabular}

\section{Список литературы}

1. ГОСТ Р 56404-2015 «Бережливое производство. Требования к системе менеджмента. М., 2015. 42 с.

2. Зарипов Р.Н. Новые образовательные технологии в подготовке инженеров для наукоемких производств: автореф. ... д-ра пед. наук: 13.00 .08 Теория и методика проф. образования. Казань, 2001. 42 с.

3. Колзина А.Г. Применение педагогической системы обучения взрослых в подготовке преподавателей внутрифирменного обучения // Проблемы современного педагогического образования: сб. науч. тр. (Вып. 62). Ялта, 
2019. $317 \mathrm{c}$.

4. Кузьмина Н.В. Понятие «педагогической системы» и критерии ее оценки // Методы системного педагогического исследования / под ред. Н.В. Кузьминой, 2-е изд. М.: Народное образование, 2002.

5. Масалимова А.Р. Корпоративная подготовка наставников. Казань: ПечатьСервис XXI век, 2013. 183 с.

6. Орехов В.Д. Особенности корпоративного обучения менеджеров // Управление персоналом. 2002. № 5. С. 26-30.

7. Педагогическая система: теория, история, развитие / под ред. В.П. Бедерхановой, А.А. Остапенко. М.: Народное образование, 2014. 128 с.

8. Туюшева А.И. Опережающее внутрифирменное обучение персонала для предприятий оборонно-промышленного комплекса: автореф. ... канд. пед. наук: 13.00.08 Теория и методика проф. образования. Казань, 2016. 25 с.

9. Шихов Ю.А., Шихова О.Ф. Экспертные методы в педагогических исследованиях // Инновации в профессиональном и профессиональнопедагогическом образовании: м-лы 20 Bсерос. науч.-практ. конф. Екатеринбург, 2015. С. 164-166.

10. Peuse H. Gene. Experiential Learning Models For Training Programs /NACTA Journal. 1989. № 06. P. 61-65.

11. Sugarman L. Kolb's model of experiential learning // Students, counselors and clients. Journal of Counseling and Development. 1985. № 4. P. 264-268.

Об авторах:

КОЛЗИНА Анастасия Геннадьевна - аспирант, АОУ ДПО Удмуртской Республики «Институт развития образования» (426009, Удмуртская Республика, г. Ижевск, ул. Ухтомского, 25); e-mail: asia.kolzina@ya.ru

ЗАРИПОВ Ренат Назипович - доктор педагогических наук, профессор, декан факультета управления и автоматизации, ФГБОУ ВО «Казанский национальный исследовательский технологический университет» (420015, Республика Татарстан, г. Казань, ул. К. Маркса 72, В-127); e-mail: renatnazipovich@rambler.ru

\section{MODEL FOR TRAINING IN-COMPANY TEACHERS OF AN INDUSTRIAL ENTERPRISE}

\section{A.G. Kolzina ${ }^{1}$, R.N. Zaripov ${ }^{2}$}

${ }^{1}$ Institute for the Development of Education, Izhevsk, ${ }^{2}$ Kazan National Research Technological University, Kazan

External training does not always take into account the specifics of a particular production, so it is more appropriate to train in-company teachers from among authoritative specialists who are able to transfer their own professional experience and knowledge. The authors describe a model for training in- company teachers. The advantage of the model are accounting the individual characteristics of the teacher, and educational needs of the companies', which is guided by the Federal and regional policy of increasing efficiency and implementing lean production.

Keywords: in-company training, in- company teachers, teaching competencies, pedagogical system, andragogy. 